\title{
Isolation, Partial Characterization and Utilization of a Polysaccharide from Bacillus megaterium ATCC 19213
}

\author{
By T. R. CASSITY AND B. J. KOLODZIEJ* \\ Department of Microbiology, The Ohio State University, $484 \mathrm{~W}$ 12th Avenue, \\ Columbus, Ohio, USA
}

(Received 5 July 1983; revised 26 September 1983)

\begin{abstract}
A high molecular weight polysaccharide was isolated from Bacillus megaterium ATCC 19213 cultured on a fructose mineral salts medium. This polymer was a heteropolysaccharide composed of D-glucose, D-xylose, D-galactose and L-arabinose in molar concentrations of $7 \cdot 7: 1 \cdot 1: 1 \cdot 0: 0 \cdot 6$, respectively. The polysaccharide neither bound concanavalin A nor formed a coloured complex with iodine, distinguishing it from many of the glucans isolated from other sporeformers. The concentration of the polymer decreased during forespore development, suggesting that it served as a carbon storage compound for use during formation of the spore.
\end{abstract}

\section{INTRODUCTION}

Many of the polysaccharides produced by spore-forming bacteria have been previously characterized. Barry et al. (1953), Goldemberg (1972), Slock \& Stahly (1974) and Strasdine (1968) described intracellular polysaccharides isolated from Bacillus megaterium, Bacillus stearothermophilus, Bacillus cereus and Clostridium botulinum, respectively, which were similar in that each was a glycogen or amylopectin-like polymer composed solely of glucose. Each of these polysaccharides was hydrolysed by an amylase, and each reacted with iodine to yield a coloured complex with an absorption maximum near that reported for iodine complexes of amylose, amylopectin or glycogen. Aubert (1951) isolated, from Bacillus megaterium KM, a heteropolysaccharide composed of D-glucose, D-galactose and D-ribose that was extractable with boiling water, and therefore assumed to be capsular material. Tinelli (1955) reported that the carbohydrate concentration of $B$. megaterium KM decreased by $40 \%$ between stationary phase and the appearance of phase-bright spores, while the poly- $\beta$-hydroxybutyrate concentration decreased by $36 \%$ during the same period. This indicated that both of the polymers were used as sources of carbon and energy during sporulation. Slock \& Stahly (1974) showed that the glucose content of $B$. cereus strain $T$ increased during the early stages of sporulation and then decreased as the spores matured, suggesting that the $B$. cereus glucan was serving as a carbon and energy source during sporulation.

The present study describes a heteropolysaccharide produced by B. megaterium ATCC 19213 and its use as a source of carbon and energy during sporulation.

\section{METHODS}

Cultivation. Bacillus megaterium ATCC 19213 and a mutant with a smaller capsule, designated BLC-1, were grown on fructose mineral salts (FMS) medium as previously described (Cassity et al., 1978).

Isolation of small-capsule mutants. Cells from $100 \mathrm{ml}$ of a late-exponential culture of $B$. megaterium were pelleted by centrifugation at $6000 \mathrm{~g}$ for $10 \mathrm{~min}$ at $25^{\circ} \mathrm{C}$, and resuspended in $25 \mathrm{ml}$ FMS containing $1.25 \mathrm{mg}$

Abbreviations: ABMP, acid-purified Bacillus megaterium polysaccharide; BMP, Bacillus megaterium polysaccharide; Con-A, concanavalin A; FMS, fructose mineral salts medium. 
nitrosoguanidine. After incubation at $30{ }^{\circ} \mathrm{C}$ for $60 \mathrm{~min}$, the cells were pelleted, washed twice with sterile $0.85 \%$ $(\mathrm{w} / \mathrm{v}) \mathrm{NaCl}$, and resuspended in $25 \mathrm{ml} \mathrm{FMS}$. The culture was then incubated at $30^{\circ} \mathrm{C}$ for $90 \mathrm{~min}$ with agitation at 200 r.p.m., after which the cells were diluted with $0.05 \mathrm{M}$-phosphate buffer (pH 7.2) and plated on trypticase soy agar supplemented with $1 \%(\mathrm{w} / \mathrm{v})$ sucrose. After incubation at $30^{\circ} \mathrm{C}$ for $24 \mathrm{~h}$, less-mucoid colonies were picked and examined for the presence of capsule in wet mounts prepared in dilute India ink. Those colonies which were composed of cells surrounded by small capsules were propagated in $10 \mathrm{ml} \mathrm{FMS} \mathrm{before} \mathrm{being} \mathrm{layered} \mathrm{onto} \mathrm{a} 70 \%$, $60 \%, 50 \%, 40 \%, 30 \%, 20 \%$ (v/v) discontinuous Renografin-76 gradient (E. R. Squibb \& Sons, Princeton, NJ; USA) and centrifuged at $20000 \mathrm{~g}$ for $60 \mathrm{~min}$ in a swinging-bucket rotor. The cells at the $70-60 \%$ interface were removed and grown on FMS. A small-capsule mutant, designated BLC-1, was isolated by this procedure. The mutant strain was identical to the parent strain with respect to biochemical reactivity, phage and antibiotic susceptibility, and growth characteristics. The parent strain was surrounded by capsules $1 \cdot 2 \mu \mathrm{m}$ thick, whereas BLC-1 was surrounded by capsules $0.3 \mu \mathrm{m}$ thick.

Polysaccharide extraction. Bacillus megaterium cells were harvested at late-exponential growth phase and were lysed by two passes through a French pressure cell (pressure $>1400 \mathrm{~kg} \mathrm{~cm}^{-2}$ ). The large particulate matter was removed by centrifugation at $5000_{\mathrm{g}}$ for $10 \mathrm{~min}$ at $0^{\circ} \mathrm{C}$ and discarded. The supernatant was extracted with an equal volume of $0.1 \mathrm{M}$-aqueous phenol at $60^{\circ} \mathrm{C}$ as described by Wicken et al. (1973). Three volumes of ethanol $\left(-20^{\circ} \mathrm{C}\right)$ were added to the aqueous layer, and the resulting precipitate was collected by centrifugation at $20000 \mathrm{~g}$ for $10 \mathrm{~min}$ at $0^{\circ} \mathrm{C}$ and lyophilized. Nucleic acids were removed by dissolving $0.5 \mathrm{~g}$ of the lyophilized precipitate in $100 \mathrm{ml}$ distilled water at $4^{\circ} \mathrm{C}$. The $\mathrm{pH}$ was then lowered to 3.5 by the addition of acetic acid, and 0.35 volumes of ethanol were added. The resulting precipitate (primarily nucleic acids) was removed by centrifugation at $20000 \mathrm{~g}$ for $10 \mathrm{~min}$ at $0{ }^{\circ} \mathrm{C}$ and discarded. The soluble polysaccharide remaining in the supernatant was precipitated by the addition of 3 volumes of ethanol $\left(-20^{\circ} \mathrm{C}\right.$ ) and $2.0 \mathrm{~mm}-\mathrm{NaCl}$ (final concentration). The resulting precipitate was designated acid-purified $B$. megaterium polysaccharide (ABMP).

Column gel chromatography. Samples of ABMP (30 mg) were passed through a $1.5 \times 90 \mathrm{~cm}$ column packed with Bio-Gel A-1.5 m (Bio-Rad Laboratories). Samples were eluted with 0.05 M-phosphate buffer (pH 7.2) at ambient temperature, and $5 \mathrm{ml}$ fractions were collected. The void volume was determined by passing a solution of Blue Dextran 2000 (Pharmacia) through the gel. Fractions containing polysaccharide (fractions 10-17) were pooled and concentrated in an Amicon ultrafiltration apparatus using a PM30 membrane. Polysaccharide prepared in this manner was designated B. megaterium polysaccharide (BMP).

Gas-liquid chromatography. Carbohydrate standards (amylose, glycogen, D-glucose, D-galactose, D-fructose, Larabinose, D-ribose, D-trehalose, D-rafinose, D-deoxyribose, cellobiose and D-xylose) and BMP (10 mg) were hydrolysed with $1 \mathrm{ml} 4 \mathrm{M}-\mathrm{HCl}$ at $100^{\circ} \mathrm{C}$ in vacuo and treated as described by Sweeley et al. (1966). Trimethylsilyl derivatives of D-glucose, D-galactose, D-fructose, L-arabinose and D-xylose were also used as standards without being subjected to the hydrolysis procedure. Samples (1 or $2 \mu \mathrm{l}$ ) were passed through a silanized $0.3175 \times 182 \mathrm{~cm}$ stainless steel column packed with $8 \%$ Silicone SE-30 on Gas Chrom Q in a Varian Aerograph Series 2700 gasliquid chromatograph at a flow rate of $30 \mathrm{ml} \mathrm{N}$ gas $\min ^{-1}$ at $155^{\circ} \mathrm{C}$.

Analytical Methods. Culture turbidity was determined by using a Klett-Summerson photoelectric colorimeter equipped with a number 54 filter. Total carbohydrate concentration was determined by the anthrone method of Ashwell (1957). Protein and nucleic acid were assayed by the $230 / 260 \mathrm{~nm}$ method of Kalb \& Bernlohr (1977) using a Gilford model 2400 spectrophotometer. Organic phosphate was assayed as described by Ames (1966). Peptides were measured by reaction with ninhydrin (Moore \& Stein, 1948) after alkaline hydrolysis (Hirs, 1967). Amino acids within the peptides were identified and quantified on a Beckman model 116 amino acid analyser after hydrolysis with $6 \mathrm{M}-\mathrm{HCl}$ (mineral-free) at $110^{\circ} \mathrm{C}$ for $24 \mathrm{~h}$ and drying over $\mathrm{KOH}$ in vacuo.

Absorption spectra of iodine-polysaccharide complexes were measured after mixing polysaccharide (1 $\mathrm{mg} \mathrm{ml}^{-1}$ ) with an equal volume of $0.05 \mathrm{M}-\mathrm{I}_{2} / 0.10 \mathrm{M}-\mathrm{KI}$ solution. The binding of concanavalin $\mathrm{A}(\mathrm{Con}-\mathrm{A})$ was done by dissolving $1 \mathrm{mg}$ polysaccharide and $1 \mathrm{mg}$ Con-A (Sigma) in $5 \mathrm{ml} \mathrm{0.05}$ M-phosphate buffer (pH 7.2) and incubating at ambient temperature for $1 \mathrm{~h}$, then at $4^{\circ} \mathrm{C}$ for $24 \mathrm{~h}$. After incubation, the precipitate was removed by centrifugation, and the concentration of unprecipitated Con-A remaining in the supernatant was determined (Kalb \& Bernlohr, 1977).

Utilization of BMP. At intervals throughout the growth and sporulation of $B$. megaterium, $400-700 \mathrm{ml}$ of culture were removed and the bacteria separated from the medium by centrifugation at $6000 \mathrm{~g}$ for $10 \mathrm{~min}$ at $0{ }^{\circ} \mathrm{C}$. Samples $(10 \mathrm{ml})$ of cell-free medium were dialysed for $3 \mathrm{~d}$ against five changes of distilled water $(10 \mathrm{leach})$ at $4^{\circ} \mathrm{C}$. After dialysis, the total carbohydrate concentrations of the solutions were determined by the anthrone method (Ashwell, 1957). Bacteria were washed once with distilled water, and the volume of the final pellet was recorded before samples were removed to determine bacterial dry weight. To measure the content of polymeric glucose, $1.8 \mathrm{ml}$ cell slurry was mixed with $0.2 \mathrm{mi}$ conc. $\mathrm{H}_{2} \mathrm{SO}_{4}$ and heated at $110^{\circ} \mathrm{C}$ for $3 \mathrm{~h}$. After adjustment of the $\mathrm{pH}$ to 6.5 by the addition of $1 \mathrm{ml} 4 \mathrm{M}-\mathrm{NaOH}$ and $0.3 \mathrm{ml} 2 \mathrm{M}$-Tris buffer, the polymeric glucose content of the cells was determined using a glucose oxidase-peroxidase kit (Sigma) as described in Sigma Technical Bulletin no. 510. The glucose concentration of the cells was also measured before hydrolysis as a control. 


\section{RESULTS AND DISCUSSION}

The ABMP was resolved into a polysaccharide fraction and a peptide fraction by chromatography through Bio-Gel A $1.5 \mathrm{~m}$ (Fig. 1). The polysaccharide, or BMP, eluted as a single peak at the void volume, indicative of a high molecular weight $\left(>1.5 \times 10^{6}\right)$. The peptide fraction was much less uniform and had a lower molecular weight. Analysis of the hydrolysed peptide fraction revealed the presence of alanine, glutamic acid, diaminopimelic acid and glucosamine in molar proportions of $2: 1: 1: 0 \cdot 5$, respectively. These components were identical to, and in the same molar proportions as, those previously reported for $B$. megaterium peptidoglycan (Ghuysen, 1968). The BMP contained $0.5 \%$ nucleic acid, and no detectable protein. The relatively small quantity of organically bound phosphate $(0.8 \%)$ indicated that the BMP was not teichoic acid.

In order to determine if the BMP was a capsular or an intracellular polymer, the isolation of BMP from the small-capsule mutant, BLC-1, was attempted. Concentrations of BMP representing $2.13 \%$ and $2.35 \%(\mathrm{w} / \mathrm{w})$ of the cell dry weight were isolated from the parent strain and from the mutant BLC-1, respectively. This indicated that the BMP was probably an intracellular polymer.

The trimethylsilyl derivatives of the monosaccharide components of BMP were identified and the relative quantities of each determined by gas-liquid chromatography. Four monosaccharides were evident, these being D-glucose, D-xylose, D-galactose, and L-arabinose in molar proportions of $7 \cdot 7: 1 \cdot 1: 1 \cdot 0: 0 \cdot 6$, respectively. The BMP isolated from both the parent strain and BLC-1 contained the same monosaccharides in similar molar proportions. These sugars together accounted for $97.1 \%$ of the total weight of the polymer. A small amount of D-ribose $(0.4 \%)$ was also found. It is unlikely that the D-xylose, D-galactose and L-arabinose components of the BMP arose as artefacts from the hydrolysis of a glucan, as glycogen, amylose and cellobiose hydrolysed in an identical manner as the BMP yielded no monosaccharides other than glucose.

Amylose, amylopectin and glycogen form coloured complexes with iodine which give characteristic absorption spectra (Kjolberg \& Manners, 1962). In order to determine if BMP was similar to any of these polysaccharides, absorption spectra of iodine complexes of BMP, potato

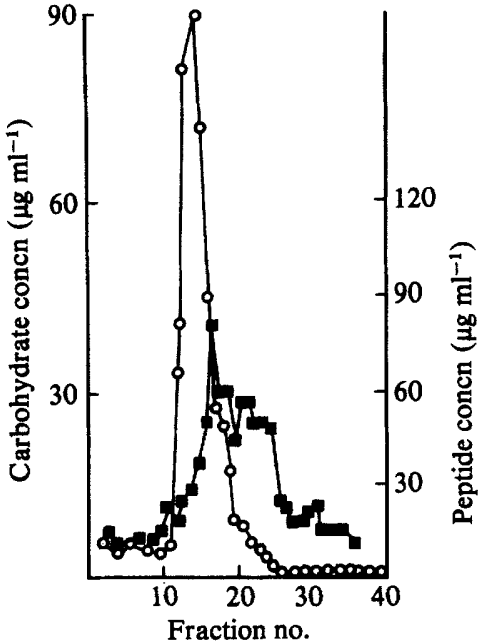

Fig. 1

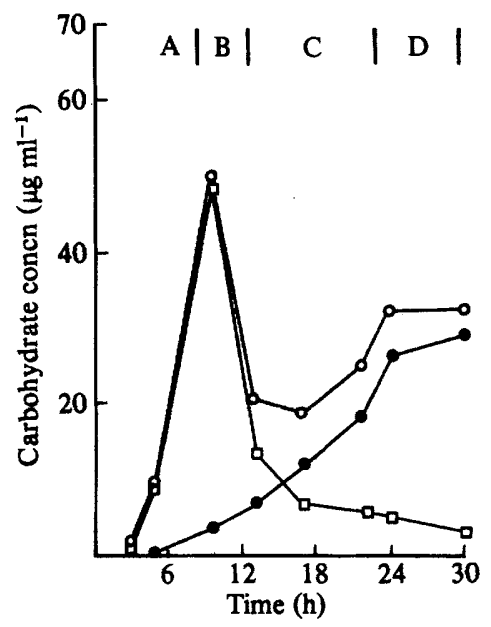

Fig. 2

Fig. 1. Column gel chromatography of ABMP through Bio-gel A1.5 m. Carbohydrate (O) and peptide (D) peaks were noted. Blue Dextran 2000, a marker of the void volume, eluted at fraction 10.

Fig. 2. Concentration of polymeric glucose in cells $(\square)$, culture supernatants $(O)$, and both $(O)$ during growth and sporulation of $B$. megaterium. Growth phases are as follows: A, exponential phase; B, forespore development; $C$, phase-bright spores in sporangia; and D, free spores. 
Table 1. Precipitation of Con-A by BMP, potato amylose, and oyster glycogen

$\begin{array}{lc}\quad \text { Polysaccharide } & \begin{array}{c}\text { Percentage of Con-A } \\ \text { precipitated* }\end{array} \\ \text { Double distilled water (negative control) } & 0.0 \\ \text { BMP } & 2.5 \\ \text { Potato amylose } & 41.7 \\ \text { Oyster glycogen } & 75.3\end{array}$

- Values represent the percentage of Con-A removed from solution as a precipitate by an equal weight of polysaccharide.

amylose and oyster glycogen were obtained. It was noted that BMP did not form a coloured complex with iodine.

To discern if the BMP contained $\alpha$-linked terminal glucose residues, it was tested for its ability to precipitate Con-A. The small amount of Con-A precipitated by BMP was considered to be insignificant (Table 1).

Even though most sporeformers produce glucans (Barry et al., 1953; Goldemberg, 1972; Slock \& Stahly, 1974; Strasdine, 1968), Aubert (1951) described a heteropolysaccharide from $B$. megaterium KM that was composed of glucose, galactose and ribose, which he assumed to be of capsular origin. The BMP appeared to be different in both location and composition. The failure to form coloured complexes with iodine also indicates that the BMP was different from the glucans produced by other sporeformers. The relative inability of BMP to bind Con-A suggests that the polymer does not contain accessible $\alpha$-linked terminal glucose residues, or that it is a long, unbranched polymer (Goldstein, 1972).

The BMP polymer contains a large amount of organic carbon. To ascertain if the BMP functions as a carbon storage compound, the concentration of the polymeric glucose in cells and culture supernatants was determined throughout growth and sporulation (Fig. 2). The concentration of polymeric glucose, and therefore presumably the concentration of BMP, increased sharply throughout exponential growth. During forespore formation the cellular concentration of BMP decreased sharply and stabilized as phase-bright spores appeared. Some BMP was gradually released into the medium as sporangia lysed. However, the total concentration of BMP decreased sharply during forespore formation. This suggests that the BMP was used as a source of carbon and energy for the formation of the spore, as has been shown to occur with glycans produced by other spore-forming bacteria (Slock \& Stahly, 1974; Strasdine, 1968; Tinelli, 1955).

\section{REFERENCES}

AMEs, B. N. (1966). Assay of inorganic phosphate, total phosphate, and phosphatases. Methods in Enzymo$\log \cdot 8,115-118$.

Ashwell, G. (1957). Colorimetric analysis of sugars. Methods in Enzymology 3, 73-105.

AUBERT, J. P. (1951). Etude biochimique du rendement matérial de croissance d'une bacterie aerobie: Bacillus megatherium. Annales de l'Institut Pasteur 80, 644-658.

Barry, C., Gavard, R., Milhacd, G. \& Albert, J. P. (1953). Etude du glycogen extrait de Bacillus megatherium. Annales de l'Institut Pasteur 84, 605-613.

Cassity, T. R., Kolodziej, B. J. \& Pfister, R. M. (1978). Ultrastructure of the capsule of Bacillus megaterium ATCC 19213. Microbios 21, 153-160.

GHUYSEN, J. M. (1968). Use of bacteriolytic enzymes in determination of cell wall structure and their role in cell metabolism. Bacteriological Reviews 32, 425-464.

Goldembero, S. H. (1972). Glucan biosynthesis in Bacillus stearothermophilus. I. Properties of the polysaccharide. Archives of Biochemistry and Biophysics 149, 252-258.

GoLDsTEIN, I. J. (1972). Use of concanavalin A for structural studies. Methods in Carbohydrate Chemistry 6, 106-119.

HiRs, C. H. W. (1967). Detection of peptides by chemical methods. Methods in Enzymology 11, 325329.

Kalb, V. F. \& Bernlohr, R. W. (1977). A new spectrophotometric assay for protein in cell extracts. Analytical Biochemistry 82, 362-371.

KJolberG, O. \& Manners, D. J. (1962). $\alpha-1,4-$ Glucosans. XV. Structural analysis of glycogens on a milligram scale. Journal of the Chemical Society 4596-4600.

MoOre, S. \& Stein, W. H. (1948). Photometric ninhydrin method for use in the chromatography of amino acids. Journal of Biological Chemistry 176, 367-388.

Slock, J. A. \& Stahly, D. P. (1974). Polysaccharide 
that may serve as a carbon and energy storage compound for sporulation in Bacillus cereus. Journal of Bacteriology 120, 309-316.

Strasdine, G. A. (1968). Amylopectin accumulation of Clostridium botulinum type E. Canadian Journal of Microbiology 14, 1059-1062.

SWeeley, C. C., Wells, W. W. \& Bentley, R. (1966). Gas chromatography of carbohydrates. Methods in Enzymology 8, 95-108.
Tinelli, R. (1955). Étude de la biochimie de la sporulation Bacillus megatherium. I. Composition des spores obtenues par carence de different substrats carbones. Annales de l'Institut Pasteur 88, 212-226.

Wicken, A. J., Gibbons, J. W. \& Knox, K. W. (1973). Comparative studies on the isolation of membrane lipoteichoic acid from Lactobacillus fermenti 6991. Journal of Bacteriology 113, 365-372. 